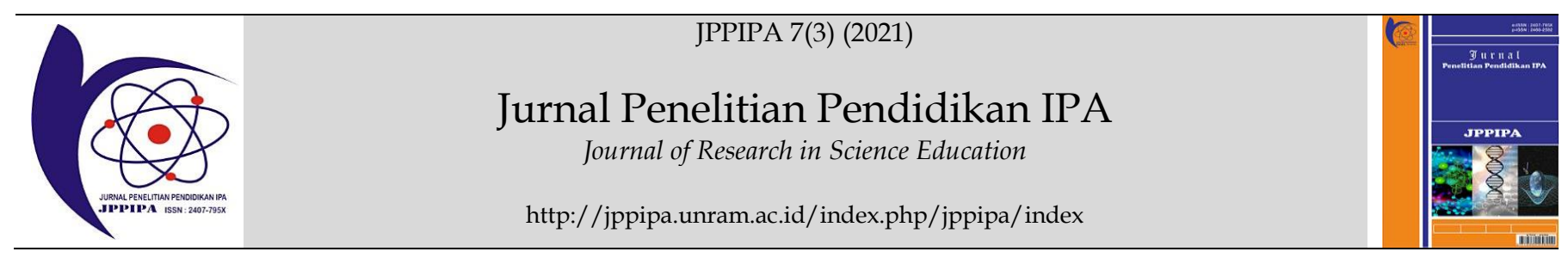

\title{
Subsurface Structure Models Of Sumbawa Island And Flores Back Arc Thrust Based On Gravity Data
}

\author{
Suhayat Minardi ${ }^{*}$ Ahmad Mudyanto $^{1}$, Hiden $^{1}$ \\ ${ }^{1}$ Departement of Physics, Faculty of Mathematics and Natural Sciences, University of Mataram, Jl. Majapahit No. 62 Mataram, West Nusa \\ Tenggara, Indonesia
}

DOI: $\underline{10.29303 / \text { ippipa.v7i3.826 }}$

\section{Article Info}

Received: April 24th 2021

Revised: July $2^{\text {th }}, 2021$

Accepted: July 8th, 2021

\begin{abstract}
Based on the BMKG report on Wednesday, July 29, 2018, at 05.47 WIB, an earthquake with a magnitude of 6.4 SR occurred at the epicenter at a depth of $24 \mathrm{~km}$ and was $47 \mathrm{~km}$ northeast of the island of Lombok. They are allegedly originating from the Back Arc Thrust Flores, the interaction between the Indo-Australian Plate and the Eurasian plate. This study aims to analyze the subsurface structure of the island of Sumbawa and Flores sea based on the distribution of density values. The analysis was carried out by modeling the subsurface structure based on regional gravity field anomaly data. The data used is secondary data downloaded from the topex.ucsd.edu page 18,400 measuring points. Data processing consists of data correction, separation of anomalies, determination of the Second Vertical Derivative (SVD) value, and 3D and 2D inversion modeling. The data corrections performed are Bouguer correction and terrain correction to produce the total gravity anomaly value. Upward continuation is used to separate regional anomalies and residual anomalies. Analysis of the Second Vertical Derivative (SVD) value was carried out to identify rock contact positions and fault structures. The 3D inversion modeling is done by making a mesh model, and to get a 2D cross-section, six slices are used in the 3D model. The results of the 3D model and 2D crosssection, namely the island of Sumbawa to the Back Arc Thrust zone of Flores, consists of 3 main layers comprised of the upper crust with a density of $2.29 \mathrm{gr} / \mathrm{cc}-2.63 \mathrm{gr} / \mathrm{cc}$, the middle crust with a density of $2.64 \mathrm{gr} / \mathrm{cc}-2.90 \mathrm{gr} / \mathrm{cc}$, and the lower crust with a density of $2.91 \mathrm{gr} / \mathrm{cc}-$ $3.14 \mathrm{gr} / \mathrm{cc}$, and based on the model and SVD value, it shows that the Flores back fault, the reverse fault type, starts at a depth of $\pm 26 \mathrm{~km}$.
\end{abstract}

Keywords: back-arc thrust; gravity anomaly; modeling; Sumbawa

Citation: $\quad$ Minardi, S., Mudyanto, A., \& Hiden, H. (2021). Subsurface Structure Models Of Sumbawa Island And Flores Back Arc Thrust Based On Gravity Data. Jurnal Penelitian Pendidikan IPA, 7(3), 414-421. doi:https://doi.org/10.29303/jppipa.v7i3.826

\section{Introduction}

The Nusa Tenggara Islands were formed due to the interaction of the Indo-Australian plate moving northward, experiencing subduction under the Eurasian plate, which moves south to form volcanic arc islands. In addition to creating islands, the two plates' interaction also creates a system of enlargement or fault, various types of sedimentary depositional basins such as trenches, forearc basins, inter-mountain or island basins, and back-arc basins (Darman and Sidi, 2000).

According to Darman (2012), the island of Sumbawa is a volcanic arc of the southeastern Nusa Islands, located between the Sunda arc in the west and the Banda arc in the east in Figure 1. On the island of Sumbawa, several volcanic activities such as Mount Tambora and Sangiang Api. , while Sangenges, Soromandi, and Maria had already eroded a quarter of their cones (Sudrajat et al., 1975). In the north of the 
island of Sumbawa, there is a fault rising behind the arc, which is often the center of shallow seismicity activity around the island of Sumbawa.

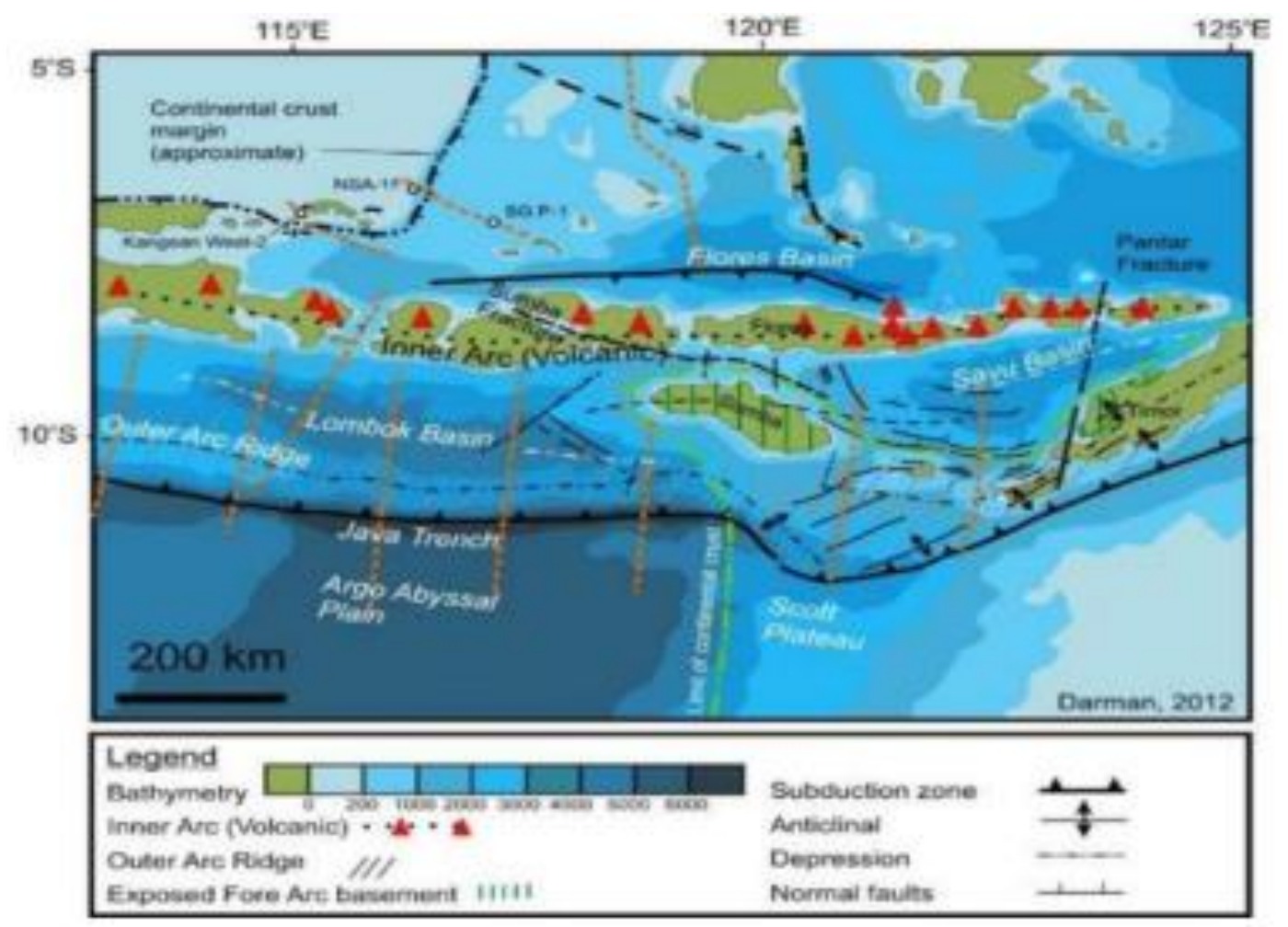

Figure 1 Physiographic and Tectonic Map of the Island of Sumbawa (Darman, 2012)

The back fault of this arc was first reported by Hamilton (1979) based on several reflection profiles found a fault in the north of the islands of Alor and Pantar on the eastern side of the back-arc of the Java subduction zone, which is commonly known as the reverse fault behind the Flores arc. At the same time, Silver et al. (1986) estimated that the fault on the west side of the Flores basin continues to the Bali basin, which is located in the north of the island of Bali.

Based on the earthquake catalog data of the United States Geological Survey (USGS) and the Meteorology, Climatology and Geophysics Agency (BMKG), most of the strong to destructive earthquakes that this back-arc thrust causes rock the Sumbawa area, and some of them are caused by back-arc thrust by plate subduction activity. The western segment of the fault is known as the Flores back arc thrust that stretches from the Northeast of Bali to the north of Flores' island. Flores back arc thrust is a generator of destructive earthquakes that will continue to threaten the arc of the islands of Bali, Lombok, Sumbawa, and Flores. This fault was the cause of the Lombok earthquake (2018), the Sumbawa earthquake (2018), and the Lombok earthquake (2019), which had a very destructive impact.

Research on gravity in Southeastern Nusa and the Flores fault has been studied and identified using the gravity method by several researchers, including Chamalaun and Grady (1978), Darman (2012), Sari (2010), Titi (2016), and Danniswara (2019). From several previous studies with gravity survey data, no one has specifically modeled the area from the island of Sumbawa to the Flores fault zone in the north of the island of Sumbawa.

The theory that underlies the survey of gravity is Newton's law of the force of attraction between two objects, where the magnitude of the force between two masses $\mathrm{m} 1$ and $\mathrm{m} 2$ separated by a distance of $\mathrm{r}$ is (Telford et al., 1990)

$$
\vec{F}=-G \frac{m_{1} m_{2}}{r^{2}} \hat{r}
$$

Where $F$ is the force $(\mathrm{N}), m 1$ and $m 2$ are the mass of the first object and the mass of the second object $(\mathrm{kg}), \mathrm{r}$ is the distance between two things, $r^{\wedge}$ is the unit vector from $m 1$ to $m 2, \mathrm{G}$ is the universal constant of gravity $(6.67 \times 10-11 \mathrm{~m} 3 \mathrm{~kg}-1 \mathrm{~s}-2)$ (Telford et al., 1990). The force per unit mass of a particle $\mathrm{m} 1$ which has a distance of $r$ from $\mathrm{m} 2$ is called the gravitational field of the $\mathrm{m} 1$ particle, which can be expressed as:=

$$
\vec{g}=-G \frac{M}{r^{2}} \hat{r}
$$


Where $g$ is the gravitational acceleration of the earth, the minus sign indicates that the direction of the force is towards the center of the Earth (Telford et al., 1990).

The measured variations in the earth's gravitational field are still influenced by several factors, including differences in latitude, differences in elevation/altitude, tidal conditions, effects of topography/surrounding terrain, and variations in subsurface density. (Telford et al., 1990). Mathematically it can be expressed in the following equation:

$$
\Delta g(x, y, z)=g_{o b s}(x, y, z)-g_{t h}(x, y, z)
$$

Where $\Delta g(x, y, z)$ is the gravitational field anomaly, $g_{o b s}$ $(x, y, z)$ is the observational gravitational field, and $g_{t h}$ $(x, y, z)$ is the theoretical gravitational field in the topography.

Only the subsurface density factor is taken into account in the gravity exploration, so other factors must be corrected. If the measurement data used is Satellite Survey data, the required correction consists of Bouguer correction and Terrain correction. The Satellite survey data has been converted to free air correction.

Bouguer Correction is a correction used to eliminate gravitational acceleration due to the mass between the measurement point and the geoid point. The Bouguer correction is given by the equation (Telford et al., 1990):

$$
B C=2 \pi G \rho h
$$

Terrain Correction (Field corrections) is carried out for areas that have irregular (undulating) topography. At the time of measurement, the elevation around the measurement point, usually within the inner and outer radius. So that the terrain correction (TC) can be written as follows (Reynolds, 1997):

$T C=\frac{2 \pi G \rho}{n} \cdot\left(r_{L}-r_{D}\right)+\left(\sqrt{r_{L}^{2}-z^{2}}\right)\left(\sqrt{r_{D}^{2}-z^{2}}\right)$

The density value used is the average density value of the earth's crust.

Furthermore, making a 3D Model using Inversion Modeling. Inversion modeling is a process depicted in Figure 2. However, modifying the model to obtain a better match for the computation data and observation data is done automatically. Inversion modeling is often referred to as data fitting because a model parameter is sought, resulting in a fit response to the observed data.

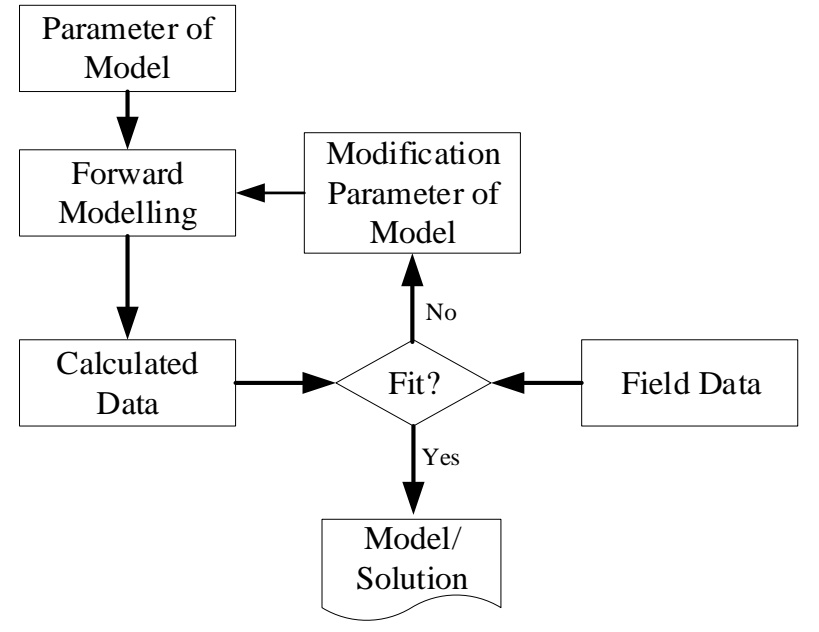

Figure 2. inversion Process

To determine the boundaries of the study area's structure, a Second Vertical Derivative (SVD) filter was used with the Elkins 1951 operator. This filter can separate residual anomalies that cannot be separated by the existing regional - residual separation method. Theoretically, this method is derived from the Laplace equation (Telford et al., 1990):

$$
\nabla^{2}(\Delta g)=0
$$

Where

$$
\nabla^{2}(\Delta g)=\frac{\partial(\Delta g)}{\partial x^{2}}+\frac{\partial(\Delta g)}{\partial y^{2}}+\frac{\partial(\Delta g)}{\partial z^{2}}
$$

\section{Method}

The data used in this study is secondary data downloaded from http://topex.ucsd.edu/cgibin/get_data.cgi which publised by Scripps Institution of Oceanography, University of California San Diego USA. The data used are free air anomaly data (FAA) and topographic data from satellite imagery. The total number of data is 14800 , with an area covering Sumbawa Island and its surroundings.

Softwares which used in the processing data are Geosoft v.6.4.2, Google Earth Pro, Surfer v.13, Quantum GIS v.2.18, and UBC.Grav3D. In addition to this software, image processing software such as Corel Draw and MS Visio are also used. Geological information is supported by the Geological Map of Sumbawa and Komodo Islands.

Data processing includes making Bouguer Anomaly (CBA) complete map, separating anomalies using the upward continuation method, 3D inversion modeling, and making SVD maps. The research stages are shown in Figure 3. 


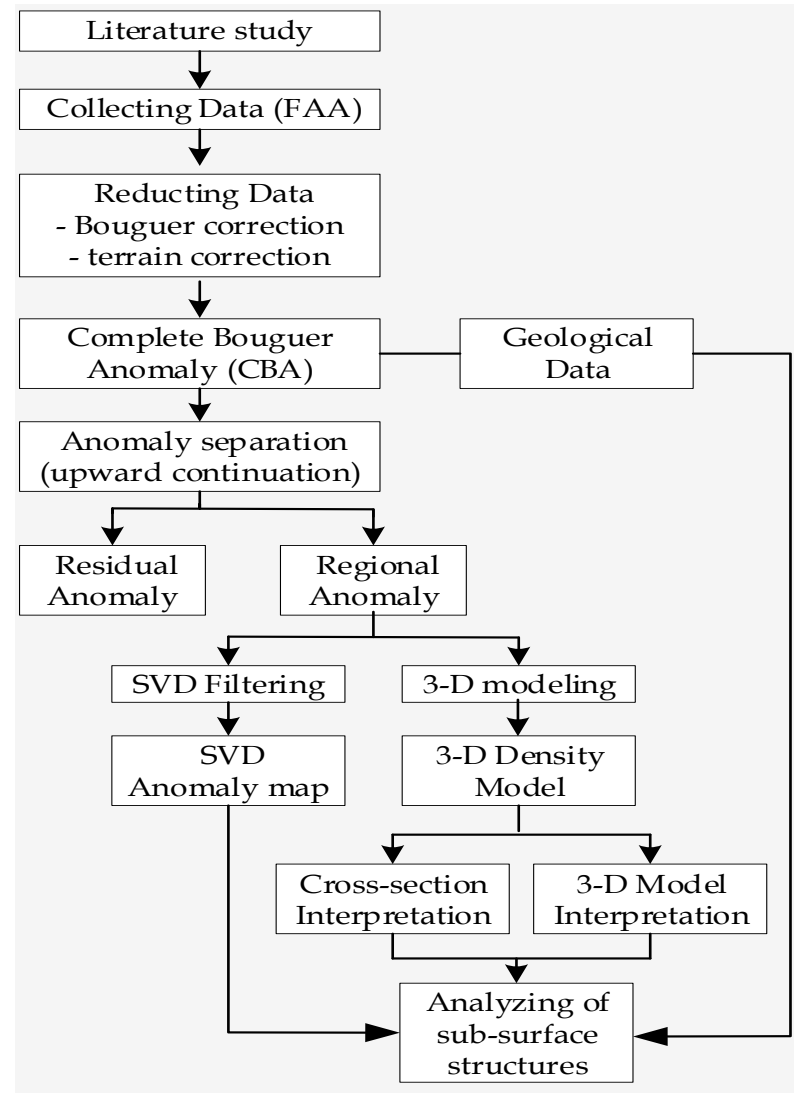

Figure 3. The research stages.

\section{Result and Discussion}

The complete Bouguer anomaly map can be seen in Figure 4. This anomaly reflects the distribution pattern of subsurface rock density. The complete Bouguer anomaly map has negative anomaly values ranging from $-40 \mathrm{mGal}$ to $464 \mathrm{mGal}$. The northeastern part of the map shows a high positive anomaly pattern, indicating that the rocks in this area have a high density. Meanwhile, the northwestern part of the island of Sumbawa and around the bay of Cempi shows a low positive anomaly to a negative anomaly which indicates a lower density than the northern part, the back fault Flores and the Flores basin.

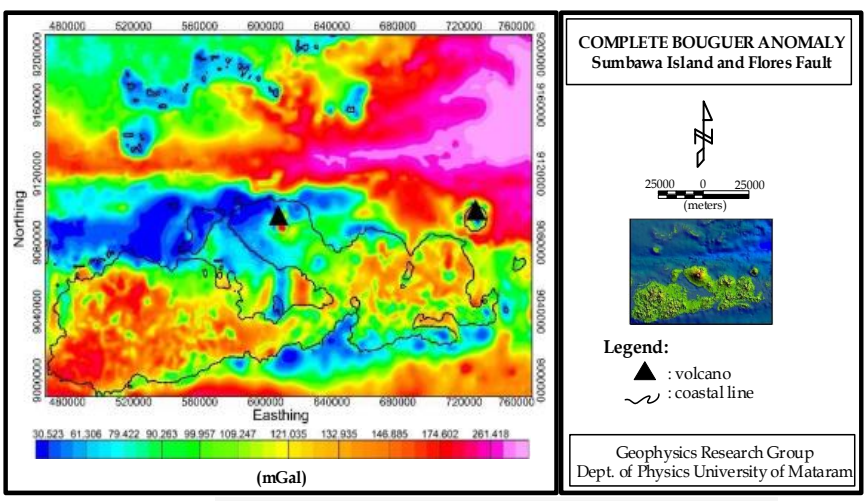

Figure 4. Complete Bouguer Anomaly (CBA) map
The high CBA value is located in the northeast part of the CBA map. Meanwhile, low anomalies in the waters northwest of Sumbawa Island and Cempi Bay are thought to be structures that uplifted at the time quarter.

As a result of the submergence of the oceanic plate, which has a density greater than that of the continental plate, there is a mass accumulation or accumulation in the subduction zone, forming volcanic arcs and basins, and back arcs. The northern part has a high anomaly because the oceanic crust of the Flores basin has plunged south under a volcanic arc. The phenomena cause the mass in the fault area and the basin to get bigger. It is in contrast to the northward subduction of the Australian continental crust.

The anomaly separation process is carried out by the upward continuation method. The results of upward continuation carried out at an altitude of 6,000 meters are shown in Figure 5. The regional anomaly values are in the range of $40 \mathrm{mGal}$ to $400 \mathrm{mGal}$

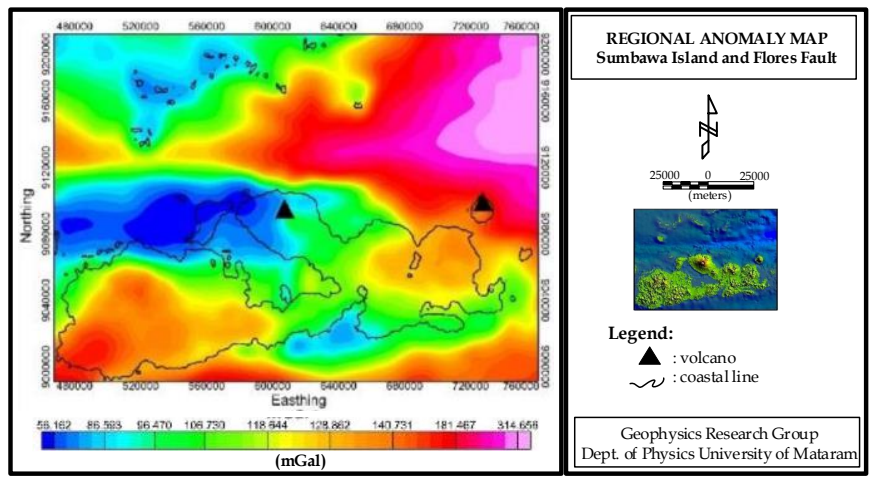

Figure 5. Regional anomaly map as a result in upward continuation at altitude 6000 meters

The sub-surface 3D modeling of the back fault zone of Flores and the volcanic arc of the island of Sumbawa based on regional anomalies are shown in Figure 6 . The results of the modeling are threedimensional layers composed of blocks with a depth of $\pm 35 \mathrm{~km}$. Based on the inversion results that have been carried out, the value range of rock density values is (2.29 - 3.14) gr/cc. Meanwhile, based on the Crustal data information, the density value model with a depth of up to $\pm 35 \mathrm{~km}$ ranges $(2.02-3.04) \mathrm{gr} / \mathrm{cc}$ 


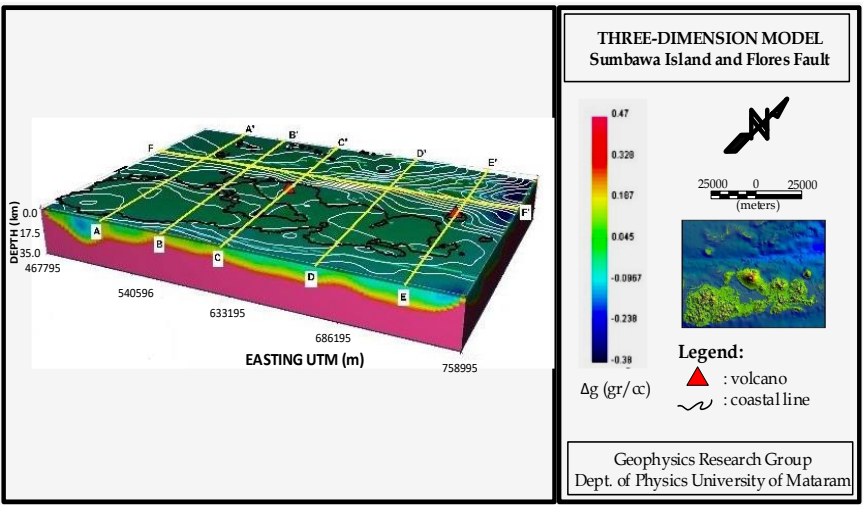

Figure 6. The subsurface 3D model based on anomaly modeling regional lift of 6000 meters

Based on the three-dimensional model in Figure 6 , the research area consists of 3 the main layer consisting of the upper crust, middle crust, and lower crust. Third layer thickness varies across study sites. For value, The density of the three layers can be seen in Table 1 below.
Table 1. Types of Rocks for each Layer in the ThreeDimensional Model

\begin{tabular}{llll}
\hline No & Layer & $\begin{array}{l}\text { Density } \\
(\mathrm{gr} / \mathrm{cc})\end{array}$ & $\begin{array}{l}\text { Thickness } \\
(\mathrm{km})\end{array}$ \\
\hline 1 & Upper Crust & $2.29-2.63$ & \pm 13 \\
2 & Middle Crust & $2.64-2.90$ & \pm 10 \\
3 & Lower Crust & $2.91-3.14$ & \pm 12 \\
\hline
\end{tabular}

From the results of the 3D model obtained, for further interpretation, a model is made the crosssection profile is north-south and west-east, aiming to find out more it is clear the gravity anomaly in the Flores fault area is caused by submergence of the plate. There are six cross-section models, namely one crosssection model east-west and 5 model cross-section direction North-South. Result model cross-section selected some model cross-section that considered could represent a model that other. The result model cross-section could be seen in Figures 7a, 7b, and 7c.

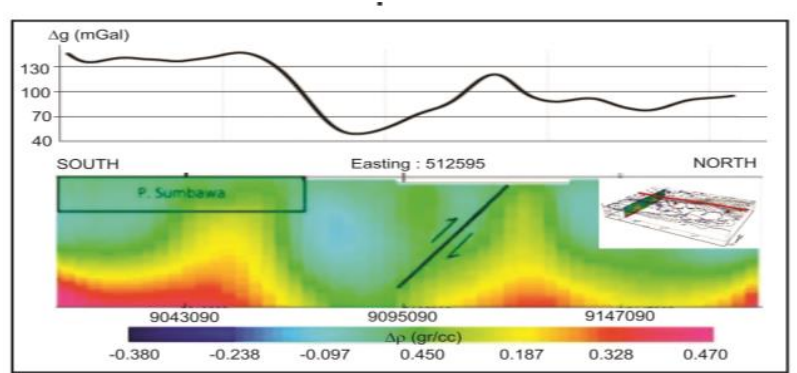

(a)

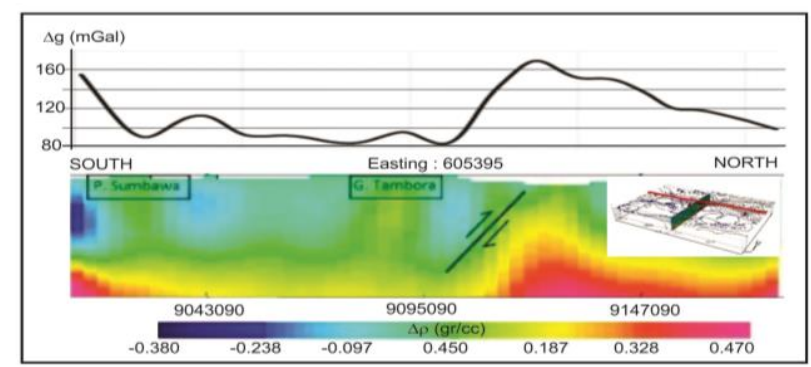

(b)

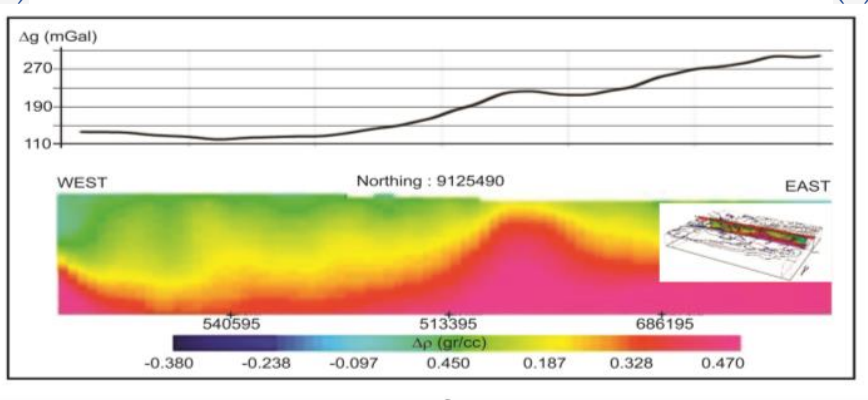

(c)

Figure 7. The result model cross-section of (a) $\mathrm{AA}^{\prime}$, (b) $\mathrm{BB}^{\prime}$, and (c) $\mathrm{FF}^{\prime}$

Figures $7 \mathrm{a}, 7 \mathrm{~b}$, and $7 \mathrm{c}$ show that the structure of the Flores Reverse Fault extends from East to West with an average increase of $26 \mathrm{~km}$ to the surface and has the same density composition so that it is possible that the rocks the constituents are the same. This is under the information from the BMKG (Widyarta et al., 2020) that the earthquake on August 9, 2018, with a magnitude of 6.9 , had a hypocenter depth of $16.1 \mathrm{~km}$, indicated to have originated from the Flores Reverse Fault as well as the earthquake incident on July 29, 2018, with a magnitude 6.4 has a hypocenter depth of $24 \mathrm{~km}$
(Hidayati et al., 2018) that, the earthquake is thought to have originated from the Flores Reverse Fault..

Furthermore, the cross-section of gravity modeling results (Figure 8a) is compared with the 6 Seismic cross-section profiles from Yang et al., 2020 study in Figure $8 \mathrm{~b}$ with the same coordinates. This is done to validate the inversion data model gravity with the result of a Seismic section. 


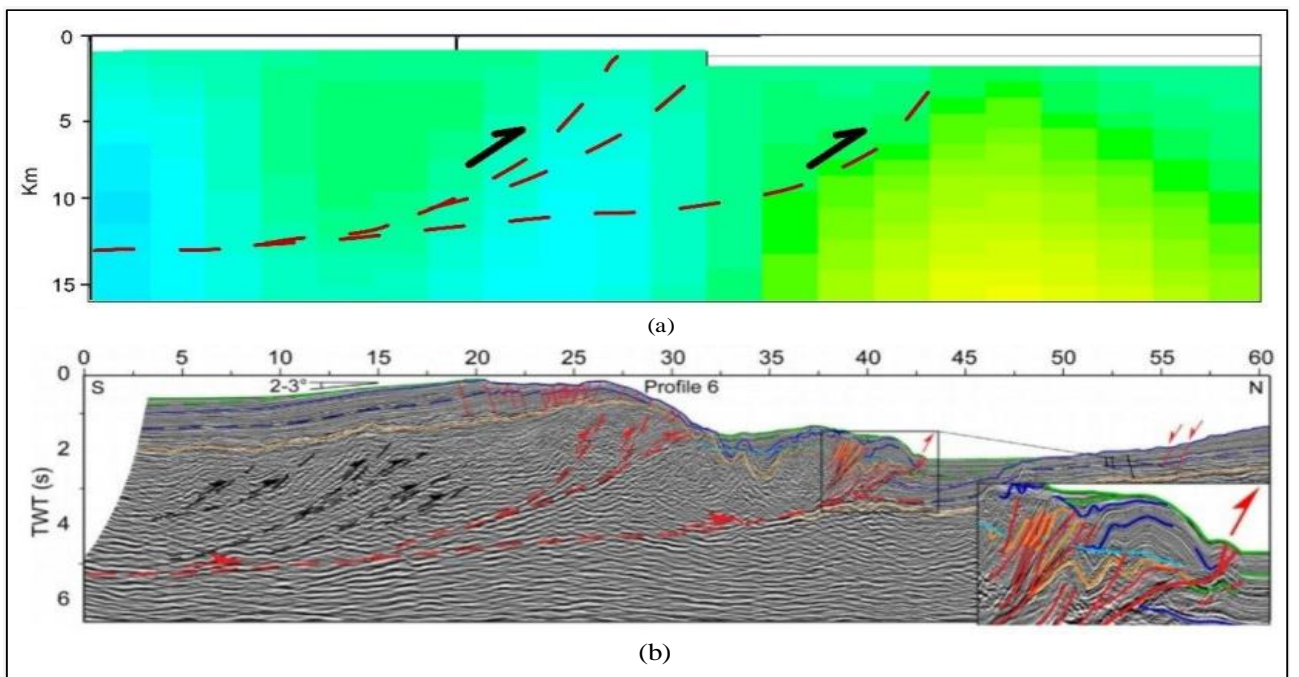

Figure 8. a). Section of Gravity b). Seismic cross-section based on research by Yang et al. (2020)

In the Gravity cross-section, a rock with a density of $\pm 2.52 \mathrm{gr} / \mathrm{cc}$ (blue color) is identified as Andesite rocks, while rocks with a density of $\pm 2.68 \mathrm{gr} / \mathrm{cc}$ (green color) identified as basalt rock. As for the seismic section of the top layer (delimited by the green line) identified as Pliocene sediments, later layers the second (delimited by brown line) was identified as the upper Miocene sedimentary layer Limestone, the two layers in the Gravity section cannot be identified, this is because the modeling is done with anomalous data regional which is an anomaly caused by the deep structure. While the lowest layer is identified as the basalt layer, there is a Fault Ascend Flores and identified to a depth of $10 \mathrm{~km}$. In contrast, on the model, the gravity of the Flores Fault was identified up to $26 \mathrm{~km}$.
Based on the comparison of gravity and seismic sections, it can be concluded that the Flores Reverse Fault is located in basalt rock, where the south side has a relative increase compared to the north side.

Filtering using the SVD method is carried out to determine the location and type of fault structure. From the SVD contour map, anomaly values ranged from $0.170 \mathrm{mGal}$ to $0.157 \mathrm{mGal}$. The existence of a fault can be indicated by the second derivative of the regional anomaly, which is equal to zero. The SVD contour map is shown in Figure 9, and the results of the crosssections are shown in Figure 10. In this study, the determination of the fault type only focused on the Flores Back arc thrust zone.
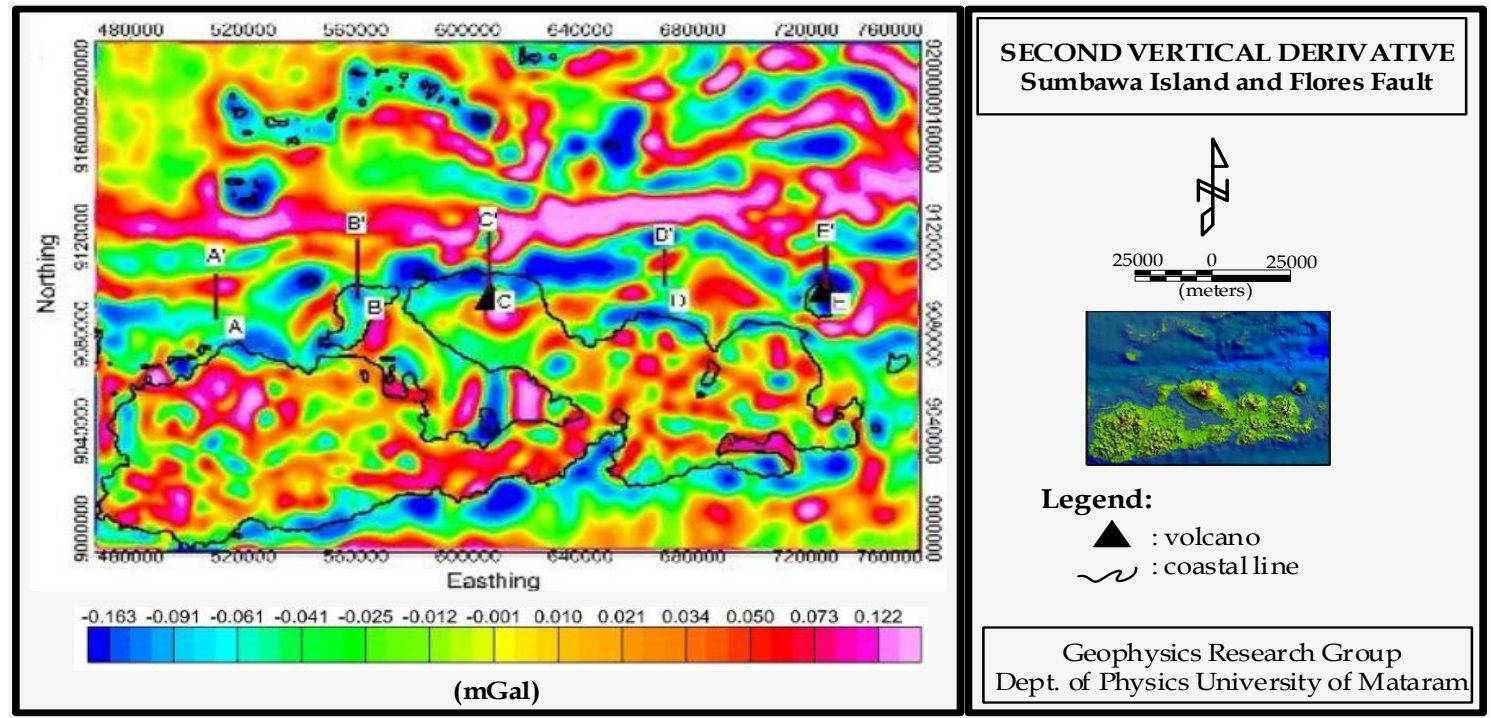

Figure 9. Map of SVD Regional Anomaly with the position of cross-sections 


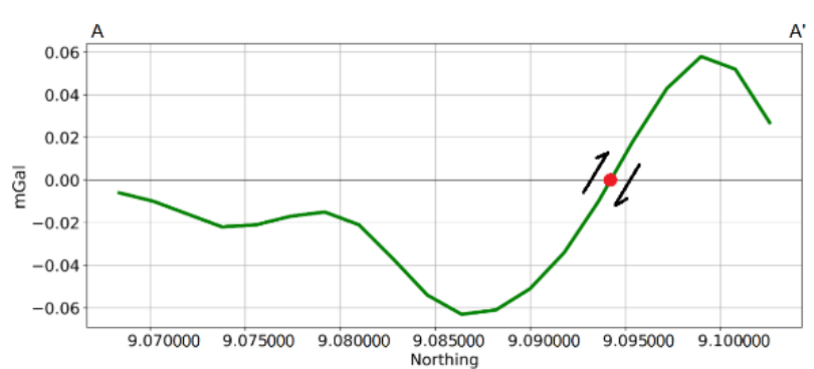

(a)

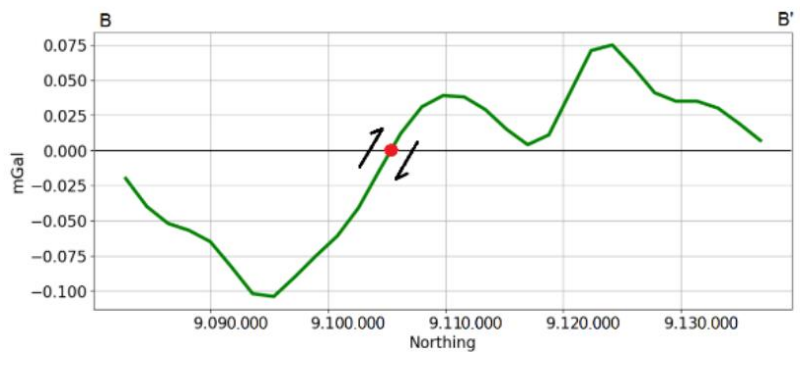

: block moving direction

(b)

Figure 10. Graph of cross-sections A-A (a) and B-B' (b) 'on the Map SVD Filter Elkins 1951

Based on the results of the five cross-sections, the SVD value shows that the Flores Fault is an Up Fault, this can be seen in the absolute value of the second derivative of the five cross-sections, where the absolute value of the minimum SVD is greater than the absolute value of the maximum SVD. The average is located in the vicinity coordinate $y=9106000.0$ UTM. The value of the results of the five cross-sections can be seen in Table 2 below.

Table 2. Absolut value of SVD

\begin{tabular}{lllll}
\hline No & $\begin{array}{l}\text { Cross- } \\
\text { section }\end{array}$ & $\|S V D\|_{\max }$ & $\|S V D\|_{\text {min }}$ & $\begin{array}{l}\text { Norting } \\
\text { Position (m - } \\
\text { UTM) }\end{array}$ \\
\hline 1 & A - A & 0.058 & 0,063 & 9093579 \\
2 & B - - B & 0.075 & 0.104 & 9106179 \\
3 & C - C & 0.098 & 0.121 & 9107979 \\
4 & D - D' & 0.077 & 0.169 & 9104976 \\
5 & E - E' & 0.068 & 0.183 & 9107979 \\
\hline
\end{tabular}

\section{Conclusion}

Based on the analysis of gravitational anomaly data and three-dimensional modeling of the subsurface structure of the Flores back fault zone and the island of Flores volcano arc can be concluded that Sumbawa island to the fault zone behind the Flores arc, three main layers are consisting of the upper crust layer with a density of (2.29 - 2.81) gr/cc composed of Granite, Andesite and Basalt rocks, the middle crust with a density range of $(2.82-2.91) \mathrm{gr} / \mathrm{cc}$ composed of Basalt, Diorite rocks, and Granodiorite, as well as the lower crust with a density range of (2.92 - 3.14) gr/cc composed of basalt, gabbro, and lava rocks. The Flores Reverse Fault is estimated to be from a depth of $26 \mathrm{~km}$ to the seafloor's surface, located in a different layer composed of Basalt, Granite and Diorite rocks.

\section{Acknowledgements}

Further thanks to Scripps Institution of Oceanography, University of California San Diego USA (topex) which has been providing data for free, and the all-parties who have supported until the completion of the study

\section{References}

Chamalaun, F.H \& Grady, A. (1978). The Tectonic Devel Opment of Timur: a New Model and us Implications for Petroleum Exploration. Australian Petroleum Exploration Association Journal, 18.

Danniswara, Risang. (2019). Identifikasi Struktur Sesar Busur Belakang Flores Menggunakan Metode Gravitasi dengan Analisa Gradien Dan Mekanisme Fokal. Other Thesis. Universitas Pembangunan Nasional Veteran. Yogyakarta. [Indonesian]

Darman, H. (2012). Seismic expression of the TimorTanimbar Trough, Eastern Indonesia. Berita Sedimentologi 24, p. 39-47. Retrieved from: www.iagi.or.id/fosi/berita-sedimentologi-no-24timor-and-arafura-sea.html.

Darman, H., Sidi,H.F., (2000), An Outline of The Geology of Indonesia. Indonesian Association of Geologist: Jakarta.

Hamilton, W. B. (1979). Tectonics of the Indonesian region. In Professional Paper. doi: https://doi.org/10.3133/pp1078

Hidayati. N., Trisnawati., Sativa. O., Wallansha. R., Sakti. A. P., Pramono. S., dan Permana. D. (2018). Ulasan Guncangan tanah Akibat Gempa Lombok Timur 29 Juli 2018. BMKG. Jakarta. [Indonesian]

Ratman, N., \& Aswan, Y. (1978). Peta Geologi Lembar Komodo Nusa Tenggara. Pusat Penelitian dan Pengembangan Geologi. Kementrian Energi dan Sumberdaya Mineral. Bandung. [Indonesian]

Sari, A.F. (2010). Pemodelan Bawah Permukaan dan Zona Subduksi Daerah Kepulauan Nusa Tenggara Timur Berdasarkan Data Anomali Medan Gravitasi Regional. Skripsi Sarjana. Universitas Diponegoro Semarang. [Indonesian] 
Silver, E. A., Breen, N. A., Prasetyo, H., \& Hussong, D. M. (1986). Multibeam study of the Flores Backarc Thrust Belt, Indonesia. Journal of Geophysical Research: Solid Earth, 91(B3), 3489-3500. doi: https://doi.org/10.1029/JB091iB03p03489

Sudradjat, A., Andi, S., Mangga, N., \& Suwarna. (1998). Peta Geologi Lembar SumbawaNusa Tenggara. Pusat Penelitian dan Pengembangan Geologi. Kementrian Energi dan Sumberdaya Mineral. Bandung. [Indonesian]

Reynold, J.M. (1997). An Introduction to Applied and Enviromental Geophysics. New York: John Willey and Sonsltd.

Telford, W.M., Geldart, L.P., \& Sheriff, R.E. (1990). Applied Geophysics, 2ndEdition. Cambridge University Press: New York.

Titi, Y.A. (2016). Pemodelan 3-D Struktur Bawah Permukaan Pulau Flores dan Zona Sesar Belakang Busur Berdasarkan Analisis Data Gravitasi. Thesis Magister. Institut Teknologi Sepuluh Nopember. Surabaya. [Indonesian]

Widyarta, R., S. K. Wijaya., M. S. Rosid., S. Rohadi. (2020). Identification of Fault Structure in Lombokregion, West Nusa Tenggara using Tomography Lombok Earthquake Data of JulyAugust 2018. IOP Conf. Series: Materials Science and Engineering. 854 012054, doi: 10.1088/1757899X/854/1/012054

Yang, X., Singh, S. C., \& Tripathi, A. (2020). Did the Flores backarc thrust rupture offshore during the 2018 Lombok earthquake sequence in Indonesia? Geophysical Journal International, 221(2), 758-768. doi: https://doi.org/10.1093/gji/ggaa018 